\title{
Flexural Behaviour, Microstructure and Cost- Benefit Analysis of Ternary Binder Foamed Concrete
}

\author{
Ashfaque Ahmed Jhatial*, Wan Inn Goh**, Rabinder Kumar***, Fida Hussain Siddiqui***, \\ Sufian Kamaruddin** and Amirul Faiz Rahman** \\ * Department of Civil Engineering, Mehran University of Engineering and Technology, Shaheed Zulfiqar Ali Bhutto Campus, Khairpur Mirs' \\ 66020, Sindh, Pakistan. \\ ** Jamilus Research Centre, Faculty of Civil Engineering and Built Environment, Universiti Tun Hussein Onn Malaysia, 86400 Parit Raja, \\ Batu Pahat, Johor, Malaysia. \\ *** Department of Civil Engineering, Mehran University of Engineering and Technology, Jamshoro 76020, Sindh, Pakistan. \\ * Corresponding Author: ashfaqueahmed@muetkhp.edu.pk
}

Submitted :31/05/2020

Revised :03/05/2021

Accepted : 16/05/2021

\begin{abstract}
Foamed concrete is a controlled low-density concrete, and due to its excellent thermal insulating and acoustic absorption properties, its application has been on a steady rise. Palm Oil Fuel Ash (POFA), an agricultural waste generated by the Palm Oil industry and Eggshells, causes many environmental problems. The pozzolanic nature of POFA and the high calcium oxide content in Eggshell Powder (ESP) are the components that contribute to their suitability as a partial cement replacement in concrete. This experimental work studied the flexural behavior, as well as the compressive strength of lightweight ternary binder foamed concrete incorporating $20 \%-25 \%$ POFA and $5 \%$ - 10\% ESP by weight of the total binder, as partial cement replacement. The test results were analyzed and compared with conventional foamed concrete without POFA and ESP. It was observed that POFA is a class C pozzolanic material. The combined utilization of POFA and ESP increased the compressive and flexural compared with control concrete. Furthermore, most of the cracks of the prisms were nearer to the middle of the samples and between two locations of loads applied due to the same load value applied at both locations. It was also observed the air voids were blocked due to increased pozzolanic activity and development of C-S-H gels and thus increase in strength. The utilization of POFA and ESP in concrete can be beneficial in reducing the overall cost. The cost to produce $1 \mathrm{~m}^{3}$ of concrete incorporating POFA and ESP was reduced ranging from was reduced by $12.59 \%$ (with 20\% POFA and 5\% ESP) to $17.53 \%$ (with $25 \%$ POFA and $10 \%$ ESP). It can be concluded that the M4 concrete mix is the optimum and cost-effective, as the maximum cement content is replaced (35\%), as well as the compressive and flexural strengths are significantly higher than the control concrete M0.
\end{abstract}

Keywords: Crack behaviour; Foamed concrete; Supplementary cementitious materials; Microstructure; Costbenefit analysis; Palm oil fuel ash; Eggshell powder. 


\section{INTRODUCTION}

Concrete is regarded as a human-made composite material that comprises cement, fine and coarse aggregates, and water. It is currently the most preferred construction and building material in the world, and also the second most consumed material after water (Lehne and Preston 2018). The popularity of concrete over other building materials is due to its ease of availability, flexibility, and durability (Manandhar et al. 2019). Despite its popularity, concrete has disadvantages such as high self-weight due to its high density and use of coarse aggregates which puts increased the dead load on the structure, depletion of natural resources, and carbon footprint due to the use of cement as a binder (Jhatial et al., 2018; Jhatial et al., 2019a). The rising cost of building materials and negative environmental impacts has forced all stakeholders in embarking on a search for alternative materials to reduce cost, develop eco-friendly concrete while at the same time maintaining or even enhancing its performance.

Foamed concrete is a potential alternative to conventional concrete due to lower densities, excellent thermal insulation, and sound absorption properties of lightweight foamed concrete has gained popularity and is widely used in the civil engineering industry due to the advantages it possesses. The density of foamed concrete can vary from 300 to $1840 \mathrm{~kg} / \mathrm{m} 3$ (Mohamad et al., 2015), compared to conventional concrete whose density ranges from 2200 to $2600 \mathrm{~kg} / \mathrm{m}^{3}$, making it significantly lighter in weight up to $87 \%$ (Jhatial et al., 2020). This can be achieved by the introduction of small particles of air void using a foaming agent during the concrete batching work. Foamed concrete has low cost and low density when compared with conventional concrete which can be an option for lightweight structure or non-load bearing component (Munir et al., 2015). Foamed concrete has been used since the early 1920s as an insulating building material, however significant research and development was not done until the late 1980s. Since then, foamed concrete has been used in many construction applications such as foundation, roof tiles, and backfill to retaining the wall (Mydin, 2014). Nowadays, foamed concrete is known as an innovative product that has some good characteristics such as self-compacting and low density. Foamed concrete consists of cement, fine aggregates, water, and foam, since no coarse aggregates are used, it contributes to reducing the rapid depletion of natural resources. The density of foamed concrete is reduced and controlled by introducing small air bubbles with the addition of stable foam. The air bubbles develop a pore structure in the matrix, which reduces the density of foamed concrete significantly as well as resists the flow of heat. The non-existence of coarse aggregates in the foamed concrete allows it to become more flowable compared to conventional concrete. Foamed concrete is also known as cellular concrete since it consists of at least $20 \%$ of volume air. Despite its advantages over conventional concrete, foamed concrete still utilizes cement as the main binder in its production, thus contributes to the emission of carbon dioxide $\left(\mathrm{CO}_{2}\right)$. According to a recent study (Suhendro 2014; Memon et al., 2021), it has been estimated that the cement industry releases approximately $10 \%$ of total global $\mathrm{CO}_{2}$ gas directly and indirectly during the production of cement. Such significant $\mathrm{CO}_{2}$ emissions contribute to the negative impact on the environment, and thus all stakeholders focus on the development of innovative concretes by utilizing waste materials as supplementary cementitious materials (SCMs), partially reducing the cement content in the production of concrete.

Furthermore, due to rapid growth across the world, an exponential number of wastes are being dumped in open landfills. These wastes cause significant management problems especially for developing countries, like Malaysia, which have prioritized economic development over sustainable solid waste management (Jhatial et al., 2021). Malaysia generates approximately 33,000 tonnes of waste daily, out of which household waste is the leading contributor, as it contributes to $65 \%$ of the total daily waste (Jabatan Pengurusan Sisa Pepejal Negara, 2012). Furthermore, it is estimated that $45 \%$ of the household waste is food and organic waste. According to Agamuthu and Fauziah (2011), 95\% of municipal waste ends up in open landfills. One such municipal food waste being dumped in open landfills is eggshells. According to the Department Veterinary Service (2020) report, in the year 2019, approximately 11.76 billion eggs were consumed in Malaysia. If the weight of the normal brown chicken egg is 52.23 grams (Altuntas, E. \& Sekeroglu, A., 2010), the eggshell is contributing to approximately 11\% (5.75 grams). If all the eggs consumed in Malaysia are brown chicken eggs, then according to the calculations, approximately 185.26 tonnes of eggshell waste are generated daily. Considering that eggshells make up to merely $0.56 \%$ of the total daily 
waste of Malaysia, however, eggshells have been categorized as a hazardous material by EU regulations (Mignardi et al. 2020). This is due to that eggshells end up in open landfills without proper treatment, and when they decompose, it develops a foul odor while attracting mice, rats, flies, and insects.

Another waste material that is being generated in abundance in Malaysia is Palm Oil Fuel Ash (POFA). To produce $1 \mathrm{~kg}$ of palm oil, approximately $4-9 \mathrm{~kg}$ of dry biomass waste is generated. POFA is one of the significant materials produced as a byproduct of the palm oil industry. It has been estimated that approximately $5 \%$ solid black ash (POFA) is produced after burning the waste materials. According to Ayub et al. (2021), the total palm oil production for 2019/2020 was 72.27 million tonnes, and as a result, 26 million tonnes of POFA is produced. For Malaysia alone, it is estimated that 10 million tonnes of POFA have been produced annually (Hamada et al., 2018). The generation of POFA has been on the rise as the production of palm oil increases. As POFA is a powders ash and is being dumped in the open air, it can cause severe health issues for the surrounding population, as well as take up valuable land.

The utilization of agricultural and industrial waste byproducts is an option to reduce the production cost of building materials, and such utilization will also reduce the environmental impact of both the concrete and the waste materials themselves. From the chemical analysis of both eggshell and POFA, it has been observed that POFA is significantly rich in $\mathrm{SiO}$, thus making it a pozzolan material while eggshell contains $\mathrm{CaO}$ content. Through many efforts of researchers, it is shown that these agro-industrial by-products have the potential to be used in building materials to replace the OPC or used along with it. Among the agricultural waste ashes, POFA consists of a higher amount of silica and pozzolanic properties, thus making it a suitable material to be used as a binder (Munir et al., 2015). POFA used as partial cement replacement enables the large utilization of agricultural waste materials. It was observed by Tonnayopas et al. (2006) that using 5\% - 30\% POFA in the concrete reduced the strength of concrete at an early stage, however, later age concrete incorporating 5\% to $15 \%$ POFA showed a gain in strength. Similar findings were observed by Sata et al. (2010), as concrete incorporating 10\% to 30\% POFA resulted in a decrease in early age compared to reference concrete. However, it was further observed that strength development was occurring and at 28 days testing showed that concrete with $10 \%$ and $20 \%$ POFA exhibited better strength than reference concrete. With 30\% POFA however, a decline in strength was observed. Chindaprasirt et al. (2007) observed that POFA, being a pozzolanic material, is a good alternative binder to be used in the production of concrete. Due to the high water absorption of POFA, it restricts the workability, however, it was observed that the compressive strength increased slightly compared to reference concrete without any POFA. But beyond the $20 \%$ substitution level, the increase in POFA content resulted in a significant decrease in strength as well as an increase in the permeability of concrete. To determine the influence on the properties of concrete when $5 \%$ to $45 \%$ POFA is used as OPC substitution, a study was conducted by Deepak et al. (2014). It was observed that POFA could replace up to $25 \%$ cement content, although the maximum strength was achieved when 15\% POFA content was used. Sooraj (2013) conducted a study on the effect of POFA on the strength of concrete, in which 0 to $40 \%$ cement content was replaced with POFA. It was observed that 20\% POFA be optimum as a further increase in POFA content reduced the strength.

Researchers have tried to reuse eggshell waste such as animal feed ingredients, fertilizer, and others. However, the majority of eggshell waste is being disposed of at landfills, which can affect human health and environmental problem. Due to this problem, several researches have been conducted to study the utilization of eggshell waste in building materials. According to Marinamarican (2015), it was observed that ESP increases the strength of concrete when utilized as partial cement replacement. Furthermore, the utilization of ESP could reduce the cost of construction and duration of construction (Bing, 2010). Yerramala (2014) partially substituted OPC content with ESP and studied its influence on the strength of concrete, and found that 5\% ESP achieved higher strength compared to the concrete without ESP content, thus suggested that 5\% ESP is the optimum level. Jhatial et al. (2019b) investigated the influence of fineness of ESP on the strength of concrete, and it was observed that finer ESP resulted in higher compressive strength, and the $10 \%$ ESP was determined to be optimum irrespective of the fineness. 
ESP and POFA are some of the major biowaste materials generated in Malaysia. Calcium Oxide $(\mathrm{CaO})$ is the main compound in the eggshells that is very similar to that of cement and presented as being composed of $93.70 \%$ calcium carbonate (Asman et al., 2017). POFA contains a higher amount of silicon dioxide, which is $55.2 \%$ that helps increase the mechanical properties (Thomas et al., 2017). Thus, it is an alternative that enables the cement to be replaced with ESP. Nowadays, many wastes such as agricultural waste have been used in the concrete mixture to decrease the amount of waste in the landfills and environmental problems. Most of the agricultural waste has been used as a supplementary cementing material due to the rising cost of cement and demand for cement. Therefore, POFA and ESP are selected as cement replacement in ternary binder foamed concrete is one of the alternatives to save the environment since the Malaysian construction industry is towards the sustainable construction and green path of construction, including energy consumption, material uses, and waste management.

\section{RESEARCH SIGNIFICANCE}

The number of eggshells is increasing day by day because it is a source of nutrient that people need every day and egg is one of the cheaper sources of the nutrient. According to the Malaysia Veterinary Department (2020), the consumption of eggs in 2012 is 9.35 billion eggs with an increasing around 400 million per year. It is estimated that consumption of eggs had reached 9403 million eggs in the year 2013. The disposal of eggshells will be equivalent to about 47000 tons of wastes to be dumped, and it will cause a serious environmental problem. Therefore, the eggshells are produced as a powder and replaced the amount of cement in concrete to reduce the eggshells wastes as well as reducing the pollution to the environment.

The main problem related to oil palm cultivation is the significantly high generation of biomass wastes (Thomas et al., 2017). Approximately $75 \%$ of the biomass wastes generated by the palm oil mills are used as a nutrient in the plantation, while the remaining amount of biomass waste is utilized by the palm oil mills to generate electricity (Umar et al., 2013). Some of the research has shown the use of the palm oil clinker to produce sustainable green concrete and palm oil shells as a lightweight aggregate.

Both POFA and ESP have been used in normal concrete and foamed concrete, but none of the research use POFA and ESP in the same concrete mix. The flexural strength and compressive strength for concrete with ESP increases with the addition of ESP (Nivedhitha and Sivaraja 2017) while the flexural strength for concrete with POFA decreases when adding POFA (Nordin et al., 2013). However, being a plant POFA has a cellulose structure that requires has significantly higher water absorption, thus reduces the workability as well as strength of concrete. The reduction in the strength can also be attributed to the pozzolanic reaction triggered by POFA, in which freely available calcium hydroxide, $\mathrm{Ca}(\mathrm{OH})_{2}$ is consumed to produce additional calcium-silicate-hydrate $(\mathrm{C}-\mathrm{S}-\mathrm{H})$ gels, which enhance the strength. However, limited $\mathrm{Ca}(\mathrm{OH})_{2}$ (approximately $22 \%$ ) which is produced due to various hydration reactions, can be consumed. Higher POFA content usage requires higher $\mathrm{Ca}(\mathrm{OH})_{2}$ content to produce C-S-H, however, with a limited supply of $\mathrm{Ca}(\mathrm{OH})_{2}$, the pozzolanic reaction is unable to produce significant $\mathrm{C}-\mathrm{S}-\mathrm{H}$ which would overcome the dilution effect caused by the reduction in cement content. The shortcoming of limited $\mathrm{Ca}(\mathrm{OH})_{2}$ can be overcome with the inclusion of ESP. Additionally, both POFA and eggshells are major wastes that are being generated in Malaysia, therefore, their combined re-utilization in concrete can be beneficial in reducing the environmental hazards due to dumping of POFA and eggshells in open-air landfills and also due to the production of cement. Therefore, this study was conducted to determine the flexural behavior in terms of flexural strength and crack pattern after added POFA and ESP will also be determined. By recycling POFA and ESP in the construction material, an environmental problem caused by mismanaging the agricultural waste can be reduced. Also, new innovative concrete from material that is readily available can be developed. This will contribute to sustainable construction where the materials used are economic, environmentally friendly, and safe. 


\section{RESEARCH METHODOLOGY}

\subsection{Materials and Mix Proportions}

The POFA was collected from a local palm oil mill near the Parit Sulong area of Johor, Malaysia. The collected POFA was initially sieved through $300 \mu \mathrm{m}$ to remove any unwanted vegetation or large particles that may have mixed with the collected POFA as the POFA was placed outside in open air. Afterwards, the $300 \mu \mathrm{m}$ sieved POFA was placed in the oven to remove any moisture. The sieved POFA was put in oven dry for 24 hours at a constant temperature of $105 \pm 5 \mathrm{oC}$ to remove any moisture. Once the oven-dry is done, the POFA was ground in Los Angles Abrasion Machine. After the grinding process, POFA became finer and was sieved again through $150 \mu \mathrm{m}$. The eggshells used in this study were collected from the bakery around Parit Raja, Malaysia, and also from FAMA, Rengit, Malaysia. The collected eggshells were washed to remove the residue and the fluid on the eggshell and were put in oven-dried for 24 hours at a constant temperature of $105 \pm 5 \mathrm{oC}$. Afterwards, the eggshells were crushed manually into the small pieces and go through the grinding process by using a blender and turned into ESP. The ESP was pass through the sieve with size $75 \mu \mathrm{m}$ to ensure the size of ESP is almost the same as the size of cement particle. The particle size distribution of the binders is shown in Figure 1. Through the particle size distribution, it was determined that approximately $96.47 \%, 84.23 \%$, and $95.95 \%$ of OPC, POFA, and ESP particles passed the $45 \mu \mathrm{m}$ sieve, respectively. Furthermore, the mean size of OPC, POFA, and ESP was $18.4 \mu \mathrm{m}, 19.6 \mu \mathrm{m}$, and $11.4 \mu \mathrm{m}$, with a specific surface area of $4870.81 \mathrm{~cm} 2 / \mathrm{g}, 4532.38 \mathrm{~cm} 2 / \mathrm{g}$, and $9740.14 \mathrm{~cm} 2 / \mathrm{g}$, respectively. The chemical composition of the binder materials is shown in Table 1. The total sum of $\mathrm{Fe} 2 \mathrm{O} 3, \mathrm{Al} 2 \mathrm{O} 3$, and $\mathrm{SiO} 2$ of POFA was determined to be $61.75 \%$, thus can be classified as Class C pozzolan according to ASTM C618 - 19. While it can be observed that ESP contains a significantly high content of $\mathrm{CaO}$, which can convert into $\mathrm{Ca}(\mathrm{OH}) 2$ when comes into contact with water. In this study, there are five different mixtures prepared with the desired density, Table 2 shows the mix proportions of ternary binder foamed concrete foamed concrete for the desired density.

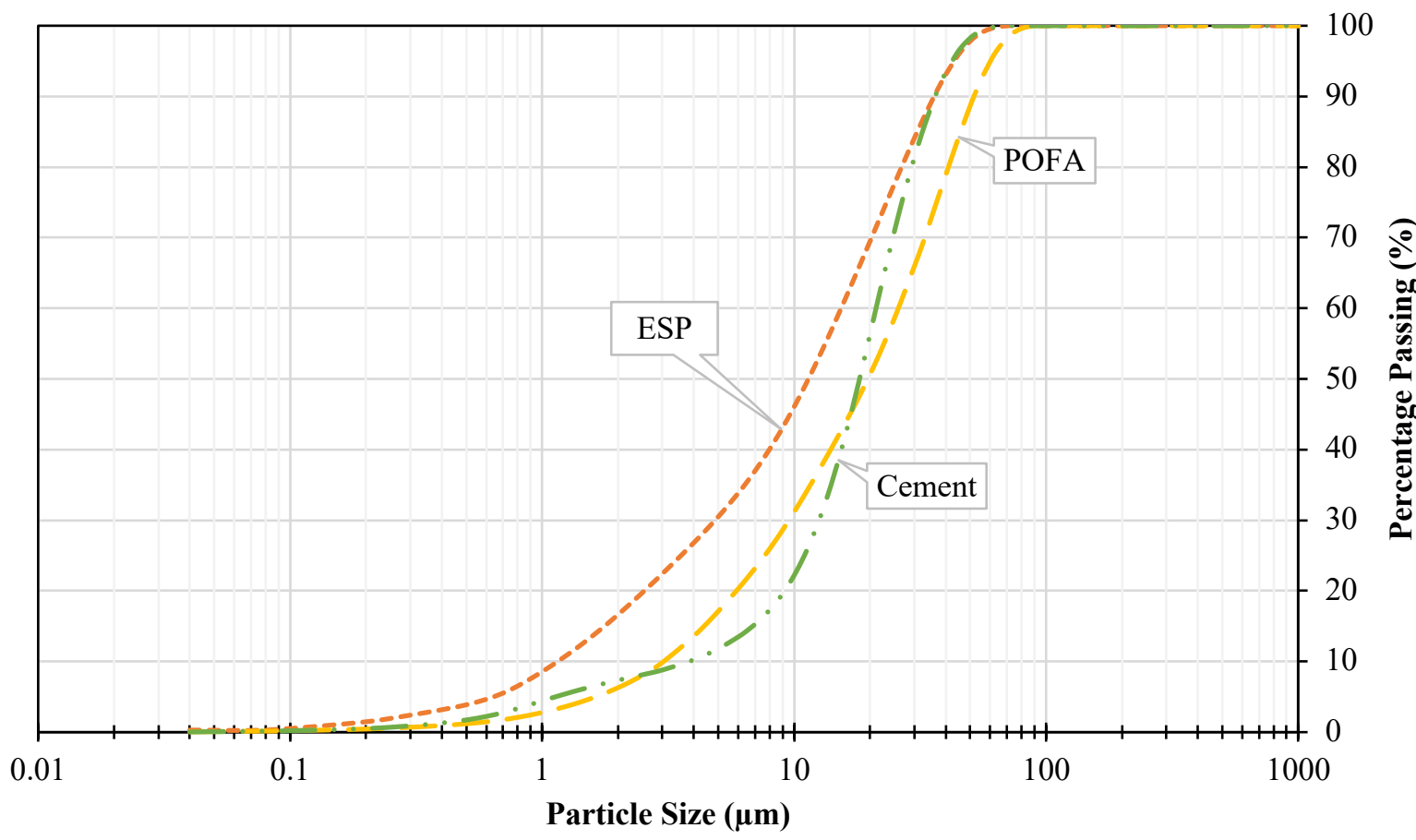

Figure 1. Particle Size Distribution Curves of OPC, ESP and POFA. 
Table 1. Chemical Composition of Binder Materials.

\begin{tabular}{|c|c|c|c|}
\hline & OPC & POFA & ESP \\
\hline $\mathbf{C a O}$ & 57.7 & 8.1 & 88.76 \\
\hline $\mathbf{S i O}_{2}$ & 14.4 & 51.83 & 1.63 \\
\hline $\mathbf{A l}_{2} \mathbf{O}_{3}$ & 3.79 & 2.32 & - \\
\hline $\mathbf{F e}_{2} \mathbf{O}_{3}$ & 2.06 & 7.6 & 0.05 \\
\hline $\mathbf{S i O}_{2}+\mathbf{A l}_{2} \mathbf{O}_{3}+\mathbf{F e}_{2} \mathbf{O}_{3}$ & - & 61.75 & - \\
\hline $\mathbf{M g O}$ & 1.96 & 3.13 & 0.91 \\
\hline $\mathbf{K}_{\mathbf{2}} \mathbf{O}$ & 0.32 & 13.72 & 0.24 \\
\hline $\mathbf{C}$ & 0.1 & 0.28 & - \\
\hline $\mathbf{S O}_{3}$ & 3.85 & 2.23 & 0.81 \\
\hline $\mathbf{P}_{2} \mathbf{O}_{\mathbf{5}}$ & - & 4.3 & - \\
\hline
\end{tabular}

Table 2. Mix Proportions and Quantity Required to Produce $1 \mathrm{~m}^{3}$ Ternary Binder Foamed Concrete.

\begin{tabular}{|c|c|c|c|c|c|c|c|c|c|}
\hline \multirow{2}{*}{ Mix } & \multicolumn{4}{|c|}{$\%$ of Binder Content } & \multicolumn{4}{c|}{ Amount of Quantity (kg) } \\
\cline { 2 - 11 } & OPC & POFA & ESP & OPC & POFA & ESP & Sand & $\begin{array}{c}\text { Water } \\
\text { (liters) }\end{array}$ & $\begin{array}{c}\text { Foam } \\
\text { (liters) }\end{array}$ \\
\hline M0 & 100 & 0 & 0 & 535.21 & 0 & 0 & 1070.42 & 294.37 & 125.06 \\
\hline M1 & 75 & 20 & 5 & 401.41 & 107.04 & 26.76 & 1070.42 & 294.37 & 125.06 \\
\hline M2 & 70 & 20 & 10 & 374.65 & 107.04 & 53.52 & 1070.42 & 294.37 & 125.06 \\
\hline M3 & 70 & 25 & 5 & 374.65 & 133.80 & 26.76 & 1070.42 & 294.37 & 125.06 \\
\hline M4 & 65 & 25 & 10 & 347.89 & 133.80 & 53.52 & 1070.42 & 294.37 & 125.06 \\
\hline
\end{tabular}

\subsection{Preparation of Ternary Binder Foamed Concrete}

The concrete mixer was filled with the specific dry raw materials (OPC, ESP, POFA, and sand) and allowed to mix for few minutes to obtain homogenous distribution. Afterwards, water was specified in Table 2 for which mix proportion was added gradually and allowed to mix for another 5 minutes such that a slurry is prepared. The wet density was measured to be $2150 \mathrm{~kg} / \mathrm{m} 3$ of the slurry. As the target dry density was $1800 \mathrm{~kg} / \mathrm{m} 3$, therefore, 1900 $\mathrm{kg} / \mathrm{m} 3$ wet density was targeted by adding foam. The foam generator was used to produce foam with a ratio of 1:20 (foaming agent to water). The generated pre-foam was added into the mix, and after the foam was mixed uniformly, the wet density was determined. This continued until the target wet density of $1900 \mathrm{~kg} / \mathrm{m} 3$ was achieved. Figure 2 illustrates the experimental procedure. Once the target wet density was achieved, the wet mix was poured into molds, and kept for 24 hours. After 24 hours, the specimens were removed from the molds and kept in air curing at room temperature of $25 \pm 5 \mathrm{oC}$, until the specified testing age was achieved. 


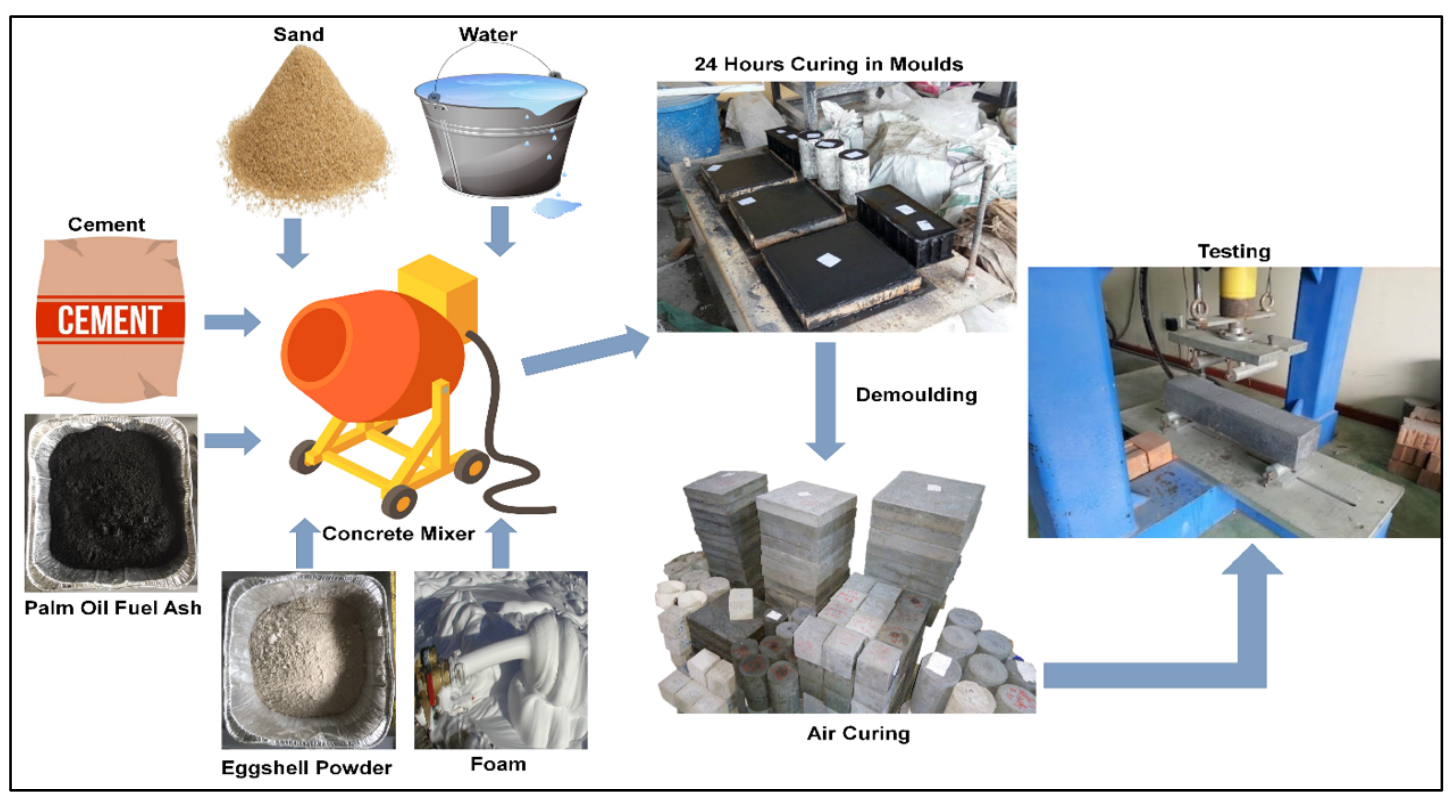

Figure 2. Flowchart of The Experiment of Ternary Binder Foamed Concrete.

\subsection{Testing Method}

Cubes of dimension $100 \times 100 \times 100 \mathrm{~mm}$ were prepared for determining the compressive strength. Once the samples achieved 7- and 28-days age, the samples were tested for compressive strength as per BS EN 12390-3:2019 using Universal Testing Machine. Four points load test was conducted to determine the flexural strength and crack pattern of ternary binder foamed concrete with the addition of POFA and ESP as partial cement replacement. The test was performed on 15 prisms with a dimension of $500 \mathrm{~mm}$ x $100 \mathrm{~mm}$ x $100 \mathrm{~mm}$, three prisms of a control foamed concrete and 12 had been tested after 28 days of curing. The BS EN 12390-5:2019 standard was referred for four points load test. Four-point load system utilizing two loads equally spaced from their adjacent support point with a distance between load points of one-third of the support span. In this study, the prisms were rested on two supports at the end of the prism, and two points loads were placed at equal distance from the adjacent support. Figure 3 shows the four points load machine and the location of support and load according to the standard.
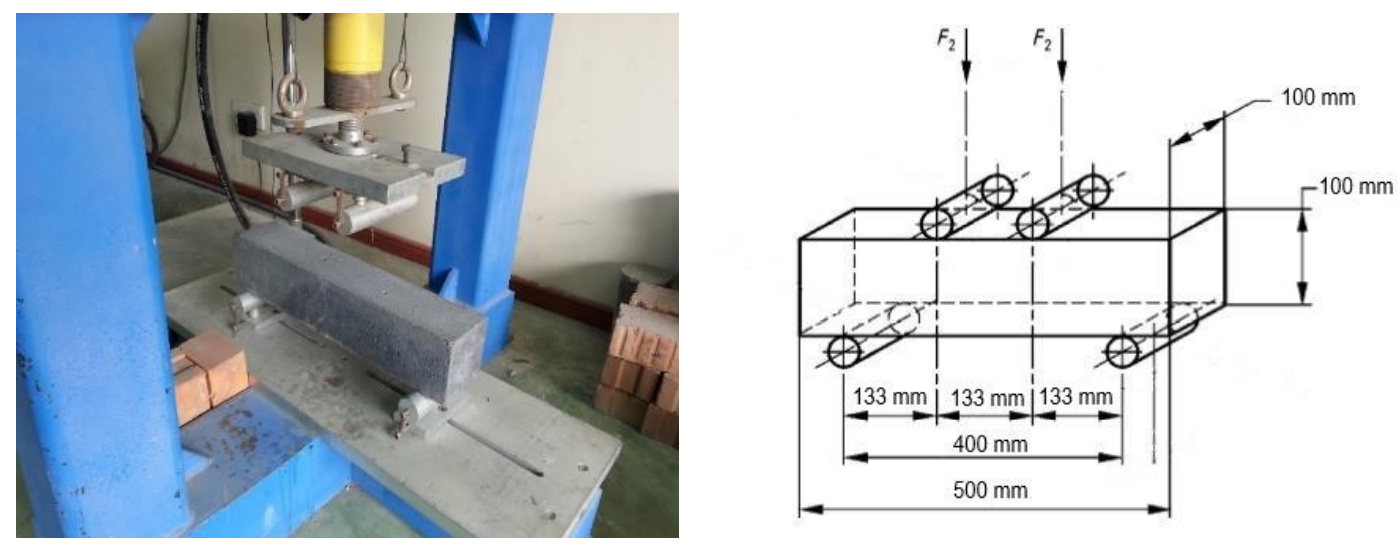

Figure 3. (a) Four points load test (b) Location of support and loads for four points load test. 


\section{RESULT AND DISCUSSION}

\subsection{Compressive Strength}

Table 3 shows the average compressive strength of the foamed concrete with and without incorporating various POFA and ESP contents. The control sample achieved 13.92 MPa on 7 days and increased to $16.96 \mathrm{MPa}$. With the $25 \%$ cement substitution using 20\% POFA and 5\% ESP (M1), the compressive strength exhibited an increase in both ages. At 7 days, the compressive strength was $16.58 \mathrm{MPa}$ which is $19.11 \%$ higher than M0, and $20.53 \mathrm{MPa}$ on 28 days which was $19.69 \%$ higher than M0. However, it can be noticed that the highest compressive strength at 7 days of 19.49 MPa was achieved by M2 while the highest 28 days compressive strength was achieved by M3. It was observed that beyond M3 which consisted of 25\% POFA and 5\% ESP (total 30\% cement replacement), the strength dropped for M4 to $13.10 \mathrm{MPa}$ and $18.10 \mathrm{MPa}$ at 7 and 28 days, respectively.

Cement consists of five major compounds, Tricalcium silicate $\left(\mathrm{Ca}_{3} \mathrm{SiO}_{5}\right)$, Dicalcium silicate $\left(\mathrm{Ca}_{2} \mathrm{SiO}_{4}\right)$, Tricalcium aluminate $\left(\mathrm{Ca}_{3} \mathrm{Al}_{2} \mathrm{O}_{6}\right)$, Tetra-calcium alumino-ferrite $\left(\mathrm{Ca}_{4} \mathrm{Al}_{2} \mathrm{Fe}_{2} \mathrm{O}_{10}\right)$, and Gypsum $\left(\mathrm{CaSO}_{4} \cdot 2 \mathrm{H}_{2} \mathrm{O}\right)$. When water is added to cement, each compound undergoes hydration which contributes to the final concrete product. However, only calcium silicates $\left(\mathrm{Ca}_{3} \mathrm{SiO}_{5}\right.$ and $\left.\mathrm{Ca}_{2} \mathrm{SiO}_{4}\right)$ are responsible for the strength development of concrete. $\mathrm{Ca}_{3} \mathrm{SiO}_{5}$ is responsible for most of the early strength (first 7 days) as shown in Eq. (1). $\mathrm{Ca}_{2} \mathrm{SiO}_{4}$, which reacts more slowly, contributes only to the strength at later times, as shown in Eq. (2).

$2 \mathrm{Ca}_{3} \mathrm{SiO}_{5}+7 \mathrm{H}_{2} \mathrm{O}--->3 \mathrm{CaO} \cdot 2 \mathrm{SiO}_{2} \cdot 4 \mathrm{H}_{2} \mathrm{O}+3 \mathrm{Ca}(\mathrm{OH})_{2}$

$2 \mathrm{Ca}_{2} \mathrm{SiO}_{4}+5 \mathrm{H}_{2} \mathrm{O}--->3 \mathrm{CaO} 2 \mathrm{SiO}_{2} \cdot 4 \mathrm{H}_{2} \mathrm{O}+\mathrm{Ca}(\mathrm{OH})_{2}$

The C-S-H and $\mathrm{Ca}(\mathrm{OH}) 2$ are reaction products. The C-S-H is the main source of strength development of concrete. Both reactions produce a limited supply of $\mathrm{Ca}(\mathrm{OH}) 2$ that is unreacted. The reaction product of $\mathrm{Ca}(\mathrm{OH}) 2$ is not desired, as it can be dissolved in water, causing leaching, and making concrete porous, and also influences the strength (Abdullah et al., 2012). Based upon the chemical composition shown in Table 1, POFA is a class C pozzolanic material (ASTM C618-19), consisting of a high content of silica. Pozzolans do not possess cementitious properties themselves, however, once they come into contact with water during mixing, it triggers a pozzolanic reaction (Jhatial et al. 2018). During the pozzolanic reaction, the freely available $\mathrm{Ca}(\mathrm{OH}) 2$ is consumed (Memon et al. 2021). as stated by Jhatial et al. (2018), $22 \%$ of the total $\mathrm{Ca}(\mathrm{OH}) 2$ produced by the hydration of cement, is available for consumption during the pozzolanic reaction. However, higher POFA content which is being used requires a higher supply of $\mathrm{Ca}(\mathrm{OH}) 2$, which is provided with the addition of ESP. The end product of the pozzolanic reaction is the development of secondary C-S-H gels as shown in Eq. (3).

$\mathrm{SiO}_{2}+\mathrm{Ca}(\mathrm{OH})_{2}=\mathrm{CaSiO}_{3} \cdot \mathrm{H}_{2} \mathrm{O}$

Thus, the addition of POFA and ESP is beneficial as it not only consumes unreacted freely available $\mathrm{Ca}(\mathrm{OH})_{2}$ but by doing so it produces secondary C-S-H gels which give additional strength to concrete. However, as for M4, the loss in strength can be attributed to excess pozzolanic content and ESP content being used, which increases the water absorption, dilution effect (due to reduced cement content), thus decrease in strength. 
Table 3. Average compressive strength of Ternary Binder Foamed Concrete incorporating POFA and ESP.

\begin{tabular}{|c|c|c|c|c|}
\hline \multirow{2}{*}{$\begin{array}{c}\text { Mix } \\
\text { Proportion }\end{array}$} & \multicolumn{3}{|c|}{ Average compressive strength (MPa) } & $\begin{array}{c}\text { The difference in strength compared } \\
\text { to the control (M0) sample }\end{array}$ \\
\cline { 2 - 5 } & 7 Days & 28 Days & 7 Days & 28 Days \\
\hline M0 & 13.92 & 16.96 & --- & -- \\
\hline M1 & 16.58 & 20.3 & $19.11 \%$ & $19.69 \%$ \\
\hline M2 & 19.49 & 21.53 & $40.01 \%$ & $26.95 \%$ \\
\hline M3 & 18.41 & 22.83 & $32.26 \%$ & $34.61 \%$ \\
\hline M4 & 13.1 & 18.10 & $-5.89 \%$ & $6.72 \%$ \\
\hline
\end{tabular}

\subsection{Flexural Strength}

Table 4 shows the average flexural strength of the foamed concrete with and without incorporating various POFA and ESP contents. Based on the result, the control sample (M0) exhibited a flexural strength of 3.1 MPa. With the $25 \%$ cement substitution using 20\% POFA and 5\% ESP (M1), the flexural strength exhibited an increase such that it achieved flexural strength of $4.03 \mathrm{MPa}$ which is $30 \%$ higher compared to M0. Further, an increase in the ESP content in M2, 20\% POFA, and 10\% ESP resulted in a slight decrease in flexural strength compared to M1, achieving $3.67 \mathrm{MPa}$, however, it was still $18.39 \%$ compared to M0 control concrete. Similarly, M3 which consists of $25 \%$ POFA and 5\% ESP exhibited flexural strength of $3.63 \mathrm{MPa}$ which is $17.10 \%$ higher compared to control M0 concrete. As for M4, which consists of $25 \%$ POFA and 10\% ESP, the flexural strength of $3.83 \mathrm{MPa}$ was obtained, which was slightly higher than M3. The variation in the flexural strength of the mixes can be attributed to the different combinations of POFA and ESP. The highest flexural strength by M1 suggests that $20 \%$ POFA supplemented with 5\% ESP exhibited the best pozzolanic reaction and strength development. From M4, it can be understood that with $25 \%$ POFA, $10 \%$ ESP is necessary for providing sufficient $\mathrm{Ca}(\mathrm{OH})_{2}$ to be consumed during the pozzolanic reaction and subsequently develop C-S-H gels.

Table 4. Average Flexural strength of Ternary Binder Foamed Concrete incorporating POFA and ESP.

\begin{tabular}{|c|c|c|}
\hline Mix Proportion & $\begin{array}{c}\text { Average flexural strength } \\
\text { (MPa) }\end{array}$ & $\begin{array}{c}\text { The difference in strength compared to the control } \\
\text { (M0) sample }\end{array}$ \\
\hline M0 & 3.1 & -- \\
\hline M1 & 4.03 & $+30 \%$ \\
\hline M2 & 3.67 & $+18.39 \%$ \\
\hline M3 & 3.63 & $+17.10 \%$ \\
\hline M4 & 3.83 & $+25.55 \%$ \\
\hline
\end{tabular}

\subsection{Crack Failure Pattern}

The crack pattern for all prim samples was determined after a 4-points load test had conducted. Figure 4 shows a crack pattern of all mixes incorporating POFA and ESP as partial cement replacement. Based on Figure 4, the cracks on two of the control samples cracked near the middle of the prisms and occurred at the flexure zone. On the 
other hand, the other one prism crack at the shear zone and near to the end of the prism. All the prism samples for M1, M2, and M4 had the same pattern of cracks. One prism from each sample cracks on the middle, near to the middle, and near to the location of the load applied. For M3 prism samples, two of the prism's cracks on flexure zone which one a prism crack on the middle of the prism and the other one cracks near to the load applied. The other sample of M3 crack on the shear zone which near the end of the prism. From the observation, most of the crack occurred at the flexure zone, which occurred between the two loads applied.
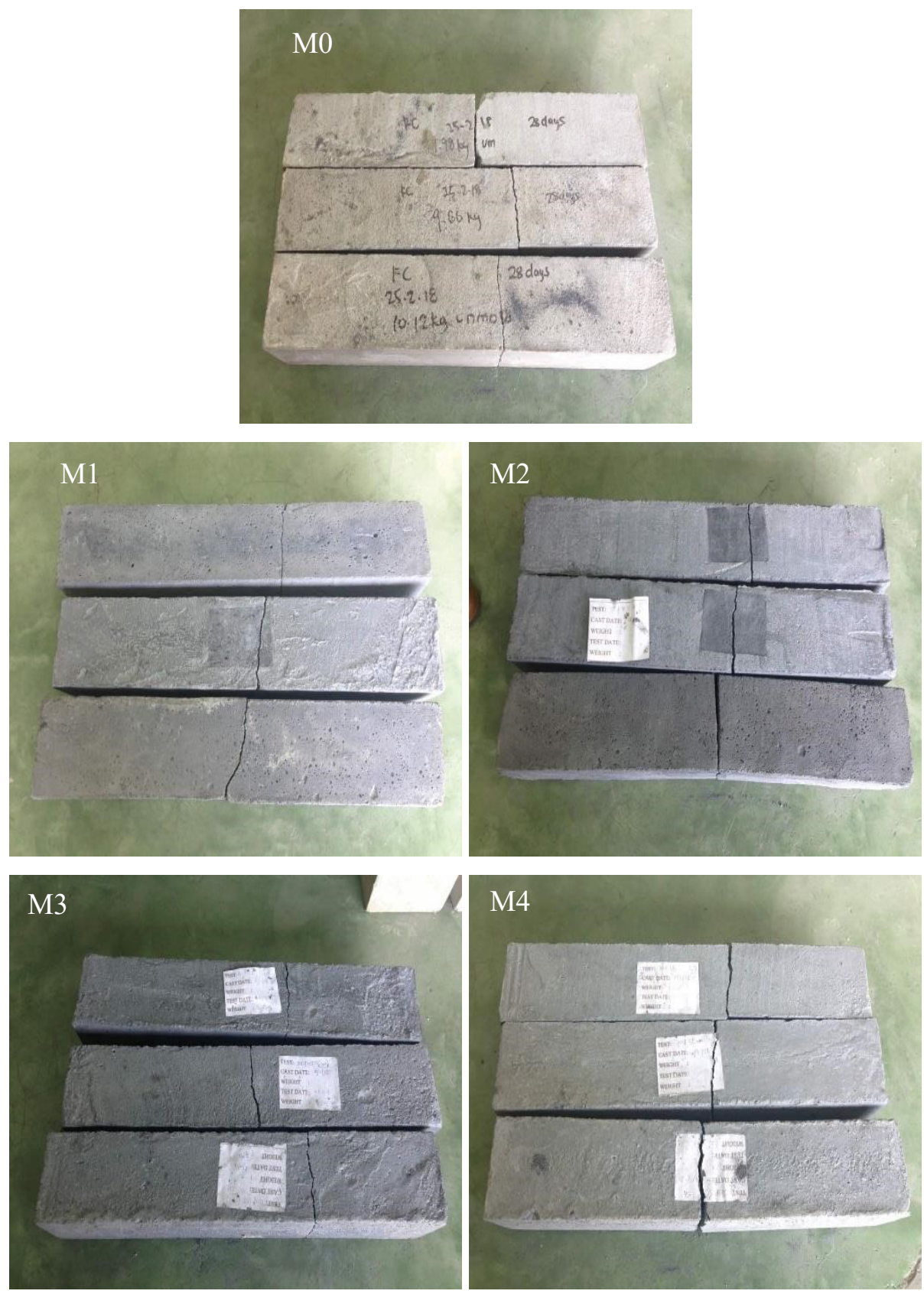

Figure 4. Crack Pattern Behaviour. 
From the observation, the crack location of each prism is based on its flexural strength. The crack occurred at the middle of the span when the load applied is high, which means the flexural strength also high compared to the prism that cracks near the end of the span. The crack also occurred in the middle of the span when the load value applied was the same at both locations. When the load value applied is not the same at both locations, the crack occurred near the end of the span. This happens due to the technical error on the flexural test machine because the machine can twist if it is not handled properly.

\subsection{Microstructure}

A crushed sample of $5 \mathrm{~mm}$ collected from samples that were tested for compressive strength was used to study the effect of POFA and ESP on the ternary binder foamed concrete at microstructure level using the Scanning Electron Microscopy (SEM). Figures showing the microstructural analysis of ternary binder foamed concrete incorporating POFA and ESP are shown in Figure 5.

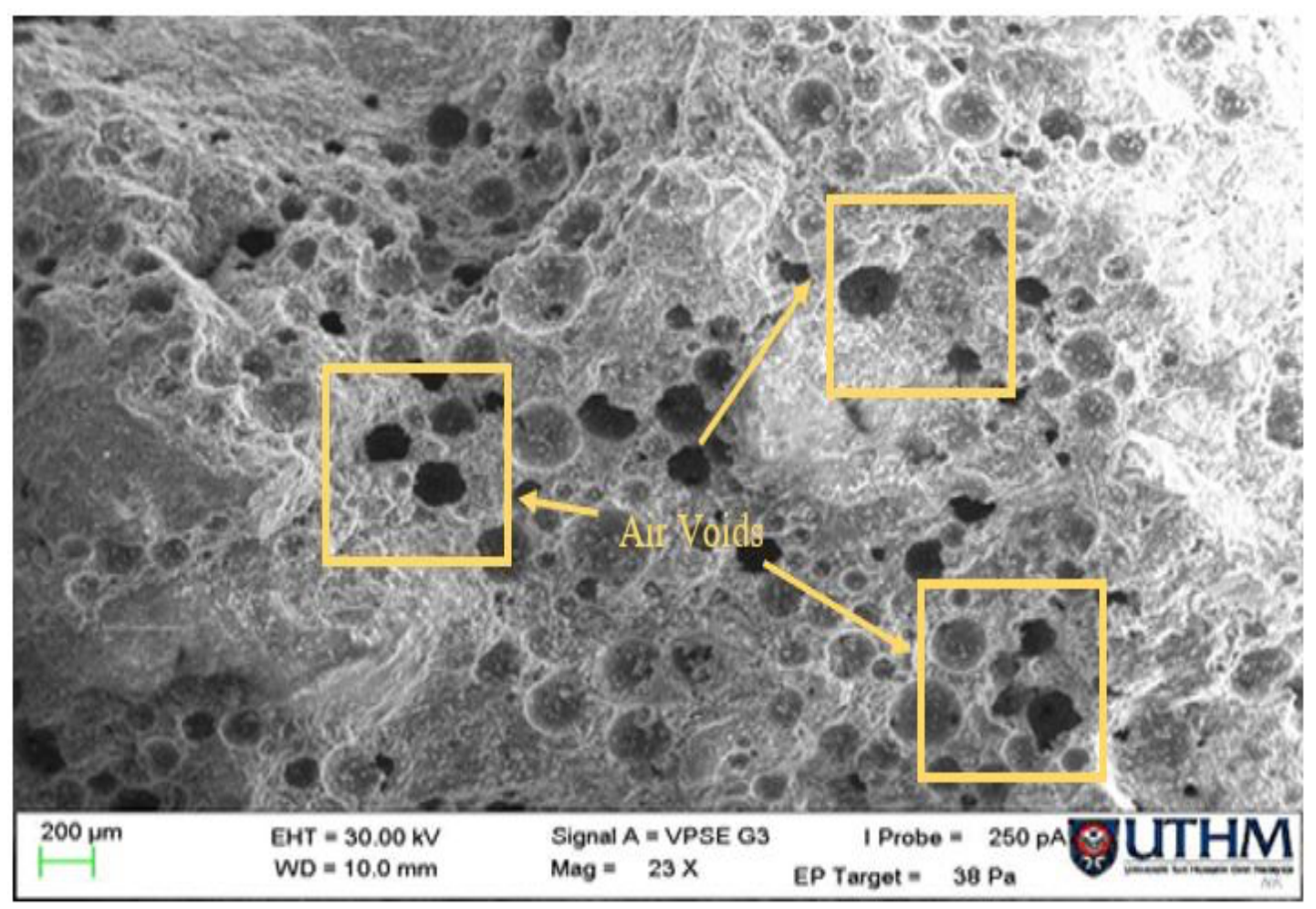



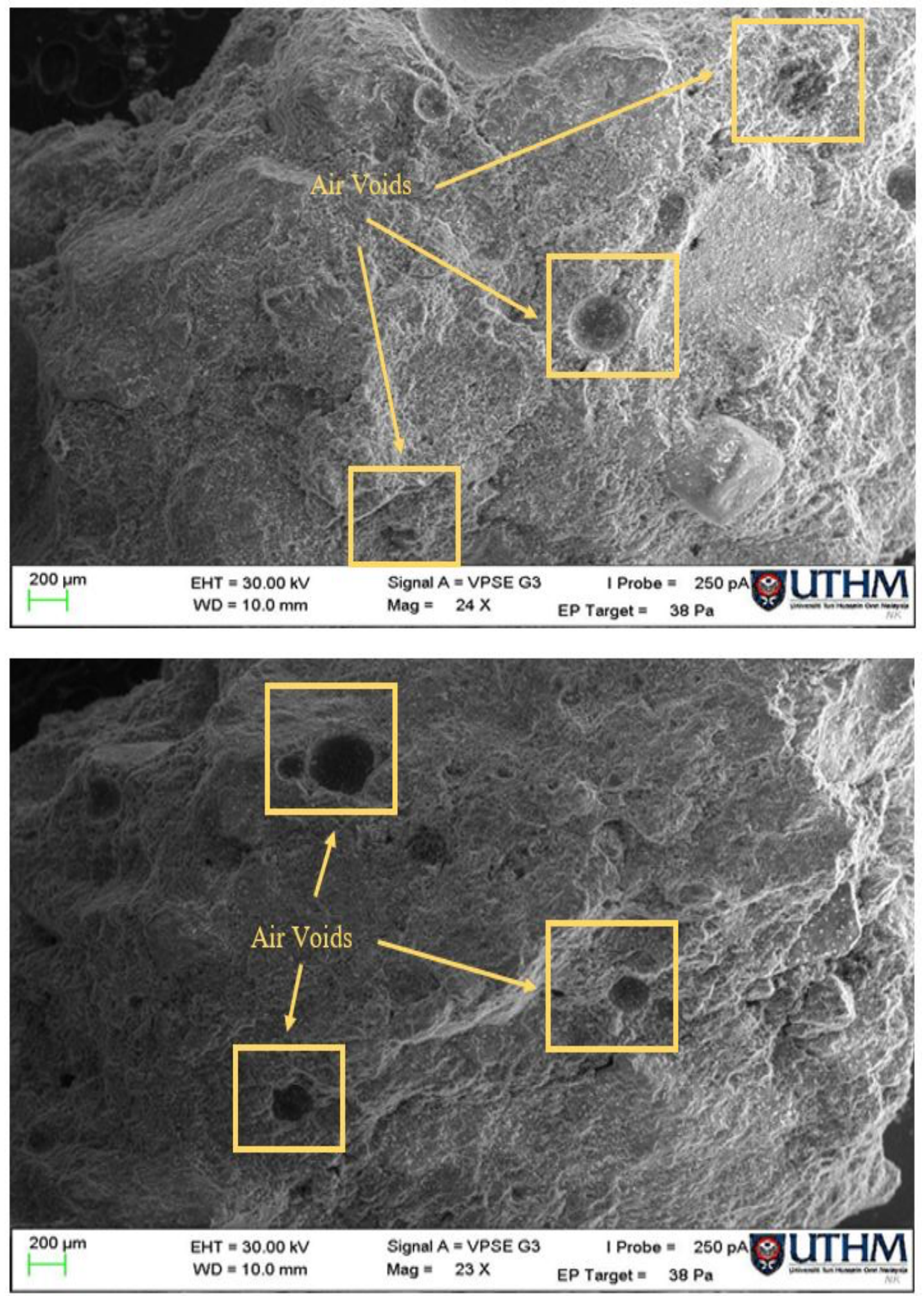

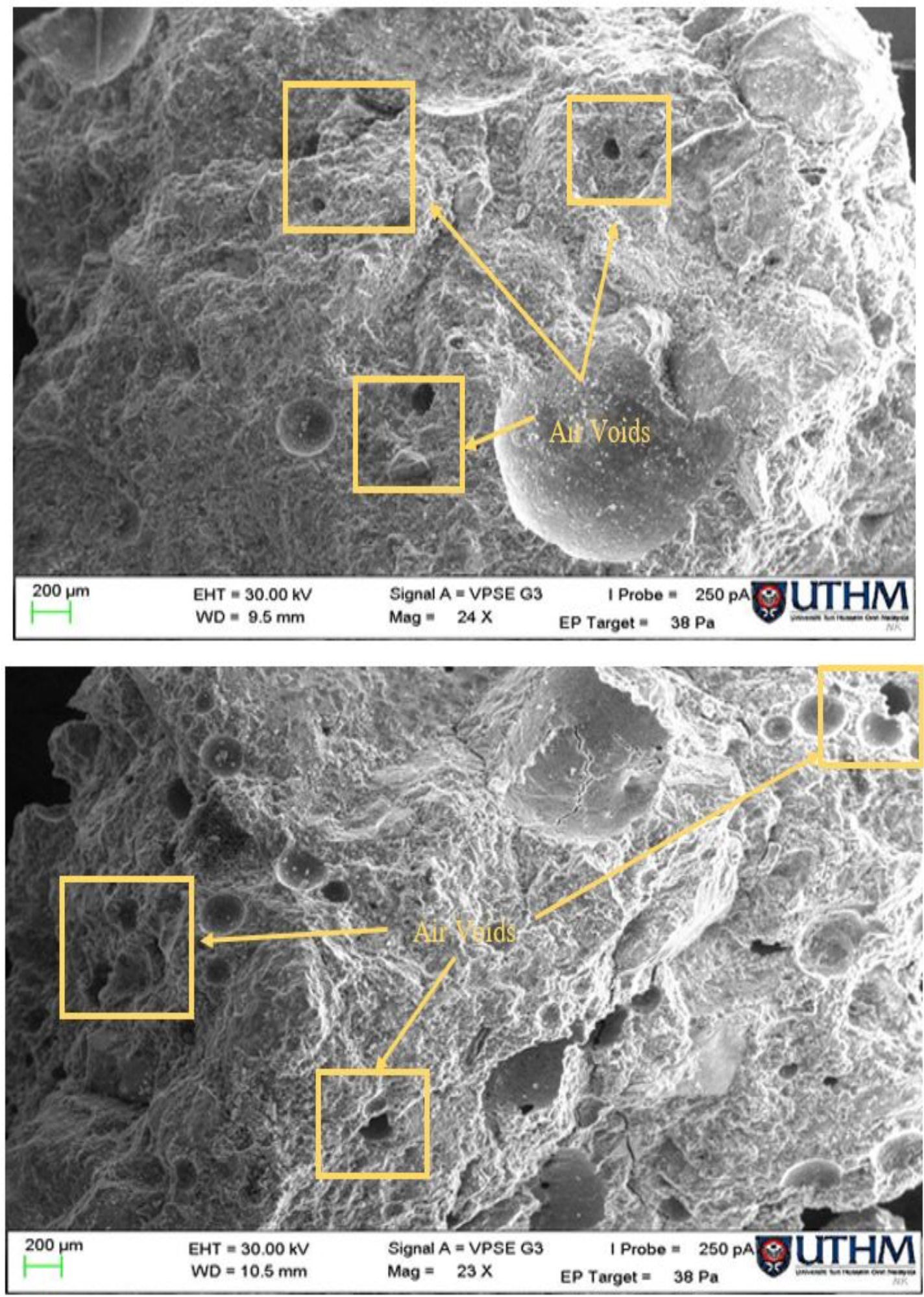

Figure 5. Microstructure Images of Samples Obtained from Different Mixes. 
The microstructure analysis of the M0 sample shows many air voids which allow it to entrap the air and help to slow down the heat transfer through the concrete medium. However, when the cement is partially replaced with POFA and ESP, the number of air voids in the matrix of ternary binder foamed concrete reduced and additional C$\mathrm{S}-\mathrm{H}$ layers are formed. The pozzolanic reaction and the nature of waste material attribute to the reduction in air voids in the matrix of ternary binder foamed concrete. During the pozzolanic activity, $\mathrm{Ca}(\mathrm{OH})_{2}$ reacts with silica-rich POFA, causing the formation of secondary $\mathrm{C}-\mathrm{S}-\mathrm{H}$ gel or layers. These layers fill up the voids and generate stronger bonding between the binder paste and the aggregates, thus achieving higher strength. This higher strength can be observed from the SEM Figures of specimens in which $20 \%$ and $25 \%$ POFA was added along with varied ESP content $(0 \%$ to $15 \%)$.

These additional C-S-H gels or layers are responsible for additional strength. Though the presence of pores in the matrix of concrete slows down the thermal conductivity or heat transfer it also reduces the strength of concrete. The immediate difference can be seen with the addition of 20\% POFA as most of the air voids which were present in the M0 sample have disappeared or have been filled with POFA content. The addition of ESP along with $20 \%$ and $25 \%$ POFA showed that the additional C-S-H layers are developed. This can be noticed with the increase in POFA and ESP content in ternary binder foamed concrete blocked or restricted the development of air voids. The reduction in air voids can be attributed to the finely ground POFA and ESP ability to coat or cover the air bubbles during wet mix such that small bubbles were prevented from merging or increasing the bubble in diameter. This has been pointed out by previous researchers that waste materials similar to fly ash tend to coat or cover bubbles (Yakovlev et al., 2016).

\subsection{Cost-Benefit Analysis}

Though the inclusion of waste materials as SCMs can be beneficial in terms of reducing the cement content, however, for it to be generally accepted by the construction industry, the developed concrete should be cost-effective. As highlighted by Jhatial et al. (2021), the combined utilization of POFA and ESP as SCMs can help reduce the total embodied carbon, as reducing the cement content reduces the carbon emissions. Though being waste materials, both POFA and ESP can be obtained in unlimited amounts for free, however, transportation and electricity consumption should be taken into consideration while calculating the cost of $1 \mathrm{~m}^{3}$ lightweight ternary binder foamed concrete. The POFA was collected from Ban Dung Oil Mill which was approximately $31 \mathrm{~km}$ from the laboratory. Though the eggshells were collected from various bakeries and food stalls around Parit Raja, however, majority of the eggshells were provided by FAMA, which was approximately $50 \mathrm{~km}$ away. Both POFA and ESP underwent various processes such as:

1. initial sieving to remove large unnecessary particles in the collected POFA,

2. removing the unnecessary fluid on the eggshells,

3. oven-drying both POFA and ESP,

4. grinding of POFA and ESP,

5. final sieving POFA and ESP through $150 \mu \mathrm{m}$ and $75 \mu \mathrm{m}$, respectively.

According to Alnahhal et al. (2018), to dry, grind, and sieve $1000 \mathrm{~kg}$ of POFA, the electricity of $25 \mathrm{kWh}$ and $149.7 \mathrm{kWh}$ is consumed, respectively. While according to Jhatial et al. (2021), to dry, grind and sieve $1000 \mathrm{~kg}$ of eggshells, the electricity of $150 \mathrm{kWh}$ and $72.84 \mathrm{kWh}$ is consumed, respectively. Therefore, taking into consideration consumption of $1 \mathrm{kWh}$ of electricity costs approximately $\$ 0.11$ and the price of 1-liter diesel costs $\$ 0.53$, assuming that the employed lorry is diesel-powered which consumes 10.1 liters per $100 \mathrm{~km}$, the calculated costs of POFA and ESP are shown in Table 5. 
Table 5. Costs of Materials.

\begin{tabular}{|c|c|c|c|c|c|c|}
\hline Materials & OPC & POFA & ESP & FA & Water & Foam \\
\hline Cost $(\$ / \mathrm{kg})$ & 0.099 & 0.0217 & 0.02417 & 0.025 & 0.001 & 6.03 \\
\hline
\end{tabular}

Based upon the cost of materials as shown in Table 5, the total cost of producing $1 \mathrm{~m}^{3}$ lightweight ternary binder foamed concrete is illustrated in Figure 6. Though it can be observed that the cost of transportation and preparation of POFA and ESP puts some price on otherwise free waste materials, however, the cost of POFA and ESP is significantly lower than OPC. The total cost of concrete decreases with the increase in POFA and ESP contents. Kamaruddin et al. (2021) studied the influence of utilizing various combinations of POFA and ESP as SCMs in the production of self-compacting concrete. It was observed that concrete in which 15\% POFA and 5\% ESP were utilized, the cost reduced approximately $7.09 \%$ compared to the control concrete without POFA and ESP. For the current study, as observed in Figure 6, the cost to produce $1 \mathrm{~m}^{3}$ of control M0 concrete was calculated to be $\$ 81.86$. By reducing 25\% cement content, M1 concrete, which incorporates 20\% POFA and 5\% ESP, the cost was reduced to $\$ 71.58$, which was $12.56 \%$ cheaper than the control M0 concrete. The cost further reduced to $\$ 67.51$ for M4, which incorporates $25 \%$ POFA and $10 \%$ ESP, this was approximately $17.53 \%$. This is in line with the findings of Kamaruddin et al. (2021). In a study by Kumar et al. (2021) substituted metakaolin, fly ash as binders and nanosilica as additive to produce high strength concrete. It was observed the substuting OPC with $30 \%$ fly ash resulted in $9.77 \%$ reduction in the total cost to produce $1 \mathrm{~m}^{3}$. However, when metakalolin and nano-silica were added along with $30 \%$ fly ash, the total cost increased upto $16.11 \%$. Kumar et al. (2021) attributed the increase in cost to the higher cost of metakaolin, nano-silica and superplasticizer used to achieve similar workability. Suggesting that some materials though may be waste materials or industrially processed, inclusion of such materials may enhance the overall properties of concrete, however, the cost of these materials is higher than the OPC, thus are not cost-effective.

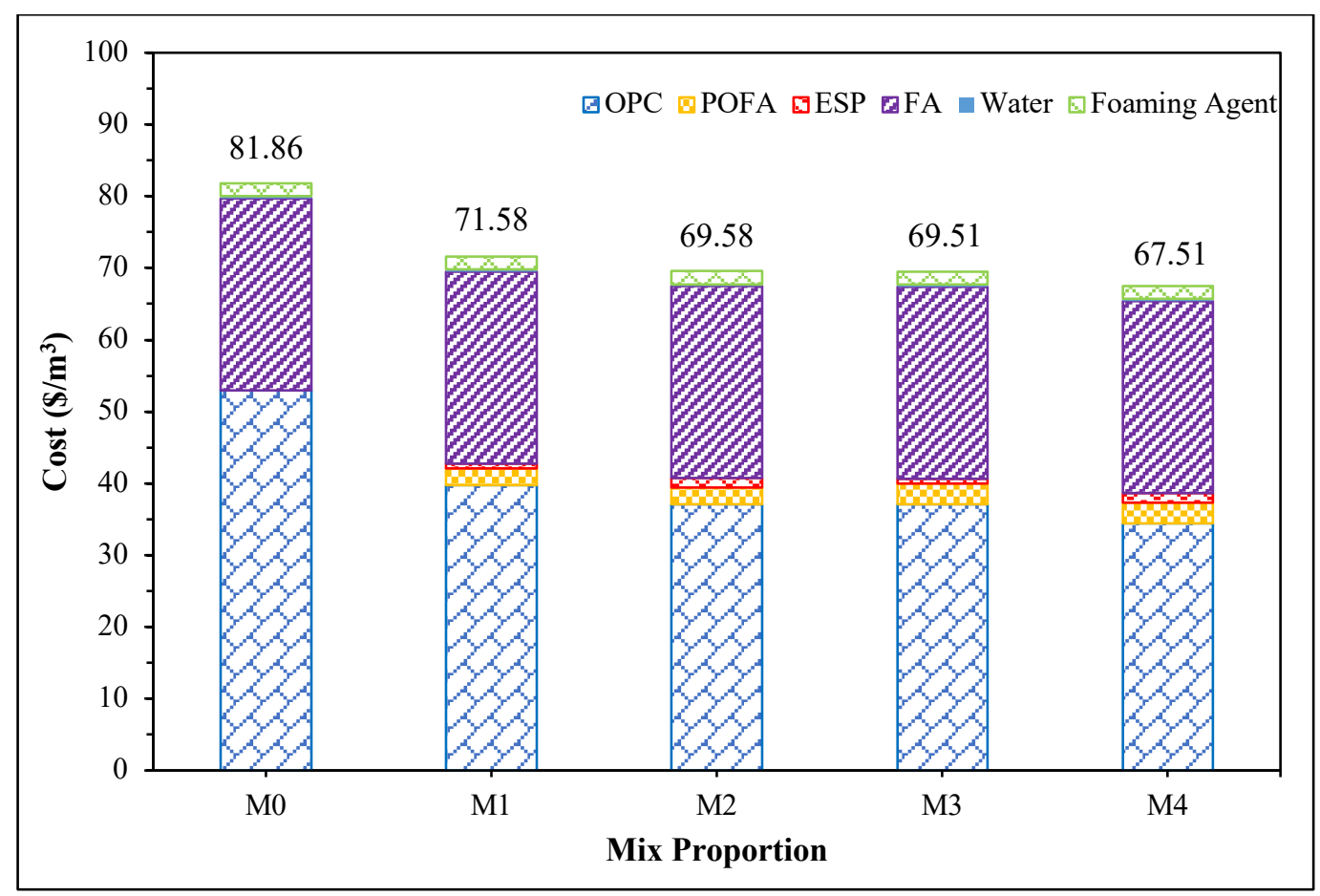

Figure 6. Cost of $1 \mathrm{~m}^{3}$ of Lightweight Ternary Binder Foamed Concrete Mixes. 
While the price of $1 \mathrm{~m}^{3}$ of concrete may vary depending upon the content of POFA and ESP, however, a cost analysis cannot complete without assessing the cost per unit strength $(1 \mathrm{MPa})$. Since the aim focus of the current study was flexural strength, therefore, the cost to produce unit flexural strength was calculated for each concrete mix, which is shown in Figure 7. It can be observed that the inclusion of POFA and ESP decrease the unit strength cost. For the control M0 concrete which has no SCM content, the cost of producing $1 \mathrm{MPa}$ flexural strength was \$26.41. The maximum cost to produce $1 \mathrm{MPa}$ flexural strength of $\$ 19.15$ was achieved by M3 which when compared to the M0 control concrete mix is $27.49 \%$ lower. While the minimum cost to produce $1 \mathrm{MPa}$ flexural strength of $\$ 17.63$ was M4, compared to the control M0 concrete, it is $33.24 \%$ lower.

In a study conducted by Kamaruddin et al. (2021), the cost per unit compressive strength was determined, for comparison, this study also calculated the cost per unit compressive strength as shown in Figure 7. It was observed by Kamaruddin et al. (2021) that different combinations of POFA and ESP resulted in different compressive strength, thus different cost per unit compressive strength. However, the lowest cost per unit compressive strength was achieved by concrete mix incorporating 5\% POFA and 2.5\% ESP, which was $\$ 0.31$ cheaper than the concrete mix without any POFA and ESP. As for current study, the lowest cost per unit compressive strength at 28 days was achieved by M3 concrete which incorporates $25 \%$ POFA and 5\% ESP. It was observed that to produce $1 \mathrm{MPa} 28$ days compressive strength, it costs approximately $\$ 3.04$, compared to control M0 concrete which costs $\$ 4.83$ per $\mathrm{MPa}$, it is whooping $37.06 \%$ cheaper. After M3, the M4 incorporating 25\% POFA and $10 \%$ ESP (total $35 \%$ OPC replacement), showed an increase in cost. This can be attributed to the lower compressive strength achieved by M4, influences the cost.

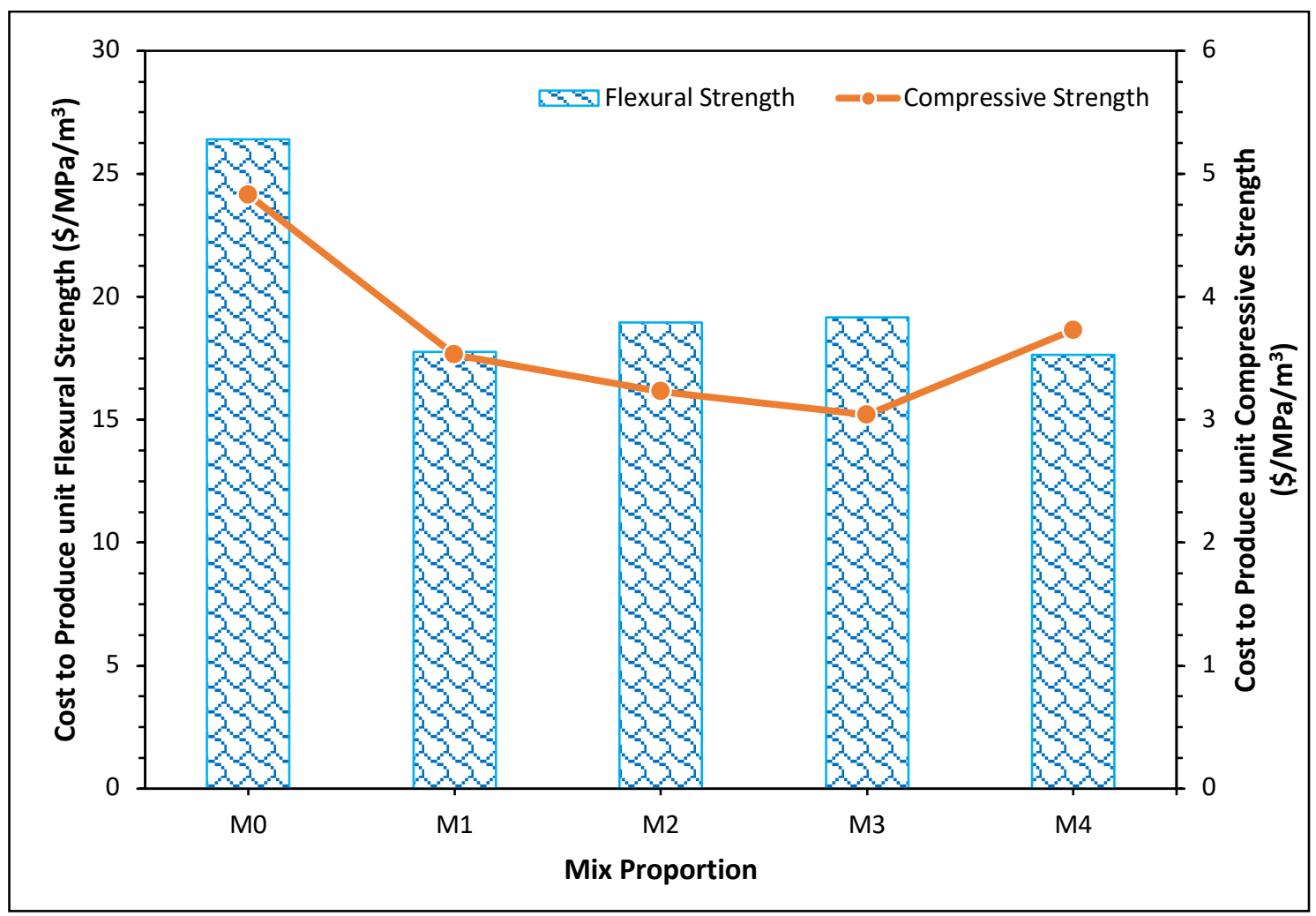

Figure 7. Unit Strength Cost of Lightweight Ternary Binder Foamed Concrete Mixes. 


\section{CONCLUSION}

The influence on the flexural behavior, in terms of flexural strength and crack pattern, of lightweight ternary binder foamed concrete incorporating 20\% and 25\% POFA and 5\% and 10\% ESP combinedly as partial cement replacement. Based upon the results, the following conclusions can be drawn:

- $\quad$ The combined utilization of POFA and ESP increased the compressive strength compared with control concrete. M3 concrete containing 25\% POFA and 5\% ESP achieved the highest strength with $22.83 \mathrm{MPa}$, an increase of $34.61 \%$ compared to the control (M0) concrete.

- Following the trend of compressive strength, concrete incorporating POFA and ESP achieved higher flexural strength. The highest flexural strength of $4.03 \mathrm{MPa}$ was achieved by M1 concrete which incorporated 20\% POFA and 5\% ESP, which was 30\% higher than the control concrete M0. However, all the concrete mixes in which POFA and ESP were utilized, exhibited significantly higher flexural strength than the control concrete.

- For the crack pattern, most of the crack of the prisms is near to the middle of the samples and between two locations of loads applied due to the same load value applied at both locations.

- $\quad$ The SEM images illustrated the blocking of air voids due to increased pozzolanic activity and development of C-S-H gels and thus increase in strength.

- The utilization of POFA and ESP in concrete can be beneficial in reducing the overall cost. The cost to produce $1 \mathrm{~m}^{3}$ of concrete incorporating POFA and ESP was reduced ranging from was reduced by $12.59 \%$ (with 20\% POFA and 5\% ESP) to $17.53 \%$ (with $25 \%$ POFA and $10 \%$ ESP).

- Subsequently, the cost to produce unit flexural strength was also significantly lowered. The control concrete cost \$26.41 to produce unit flexural strength, whereas M4 incorporating 25\% POFA and 10\% ESP, cost $\$ 17.63$.

- $\quad$ Though the highest compressive strength was achieved by M3, and flexural strength by M1, the M4 concrete mix can be considered as optimum, as the maximum cement content is replaced (35\%), as well as the compressive and flexural strength is significantly higher than the control concrete M0. Furthermore, it is costeffective, reducing the overall cost by $17.53 \%$.

\section{ACKNOWLEDGEMENT / FUNDING SOURCE}

The authors would like to appreciate and acknowledge the FRGS RACER (Fundamental Research Grant Scheme for Research Acculturation of Early Career Researchers) RACER/1/2019/TK06/UTHM/1 and FRGS Racer $\mathrm{K} 140$ for its financial support for this project.

\section{CONFLICT OF INTEREST}

The authors declare that there is no conflict of interest.

\section{REFERENCES}

Abdullah, A., Jaafar, M.S., Taufiq-Yap, Y.H., Alhozaimy, A., Al-Negheimish, A. \& Noorzaei, J., 2012. The effect of various chemical activators on pozzolanic reactivity: A review. Scientific Research and Essays, 7(7), pp.719-729. 
Agamuthu, P. \& Fauziah, S. 2011. Challenges and issues in moving towards sustainable landfilling in a transitory country - Malaysia. Waste Manag Res 29(1):13-19

Alnahhal, M. F., Alengaram U. J., Jumaat M. Z., Abutaha F., Alqedra M. A., Nayaka R. R., 2018. Assessment on engineering properties and $\mathrm{CO} 2$ emissions of recycled aggregate concrete incorporating waste products as supplements to Portland cement. Journal of Cleaner Production, 203:822-835.

Altuntas, E. \& Sekeroglu, A., 2010. Mechanical behavior and physical properties of chicken egg as affected by different egg weights. Journal of food process engineering, 33(1), pp.115-127.

Asman, N. S. A., Dullah, S., Ayog, J. L., Amaludin, A., Amaludin, H., Lim, C. H. \& Baharum, A. 2017. "Mechanical Properties of Concrete Using Eggshell Ash and Rice Husk Ash as Partial Replacement of Cement.” MATEC Web of Conferences 103, (2017): 1 - 6. doi:10.1051/matecconf/201710301002.

ASTM C618-19, 2019. Standard specification for coal fly ash and raw or calcined natural pozzolan for use in concrete. ASTM International

Ayub, M., Othman, M. H. D., Khan, I. U., Hubadillah, S. K., Kurniawan, T. A., Ismail, A. F., Rahman, M. A. \& Jaafar, J., 2021. Promoting sustainable cleaner production paradigms in palm oil fuel ash as an ecofriendly cementitious material: A critical analysis. Journal of Cleaner Production, p.126296.

Bing, L. Y., 2010. Effect of Foamed Concrete with Albumen Concrete. Degree. Thesis. Universiti Malaysia Pahang; 2010

BS EN 12390-3, 2019. Testing hardened concrete. Compressive strength of test specimens BSI Stand Ltd

BS EN 12390-5, 2019. Testing hardened concrete. Flexural strength of test specimens BSI Stand Ltd

Chindaprasirt, P., Homwuttiwong, S. \& Jaturapitakkul, C., 2007. Strength and water permeability of concrete containing palm oil fuel ash and rice husk-bark ash. Construction and Building Materials, 21(7), pp.14921499.

Deepak, T. J., Elsayed, A., Hassan, N, Chakravarthy, N., Tong, S. Y. \& Mithun, B. M. 2014. Investigation of Properties of Concrete with Palm Oil Fuel Ash as Cement Replacement. International Journal of Scientific \& Technology Research. Vol. 3 Issue 1.

Department Veterinary Service Report 2020. Consumption of livestock products, 2013 - 2019. Available from: http://www.dvs.gov.my/dvs/resources/user 1/2019/BP/Perangkaan\%20Ternakan\%2020182019/1)_Malaysia_Perangkaan_Ternakan.pdf [Accessed 23 Feb 2021].

Hamada, H. M., Jokhio, G. A., Yahaya, F. M., Humada, A. M. \& Gul, Y., 2018. The present state of the use of palm oil fuel ash (POFA) in concrete. Construction and Building Materials, 175, pp.26-40.

Jabatan Pengurusan Sisa Pepejal Negara, 2012. Survey on SW Composition, Characteristics \& Existing Practice of SW Recycling in Malaysia. Final Report.

Available from: https://jpspn. kpkt.gov.my/resources/index/user_1/Sumber_Rujukan/kajian/ Final_Report_REVz.pdf

Jhatial, A. A., Goh, W. I., Mastoi, A. K., Rahman, A. F \& Kamaruddin, S. 2021. Thermo-mechanical properties and sustainability analysis of newly developed eco-friendly structural foamed concrete by reusing palm oil fuel ash and eggshell powder as supplementary cementitious materials. Environmental Science and Pollution Research. https://doi.org/10.1007/s11356-021-13435-2

Jhatial, A. A., Goh, W. I., Mohamad, N., Rind, T. A., \& Sandhu, A. R. 2020. Development of Thermal Insulating Lightweight Foamed Concrete Reinforced with Polypropylene Fibres. Arabian Journal for Science and Engineering, 1-10. 
Jhatial, A. A., Goh, W. I., Mo, K. H., Sohu, S., \& Bhatti, I. A. 2019a. Green and sustainable concrete-the potential utilization of rice husk ash and egg shells. Civil Engineering Journal, 5(1), 74-81.

Jhatial, A. A., Sohu, S., Memon, M. J., Bhatti, N. U. K. and Memon, D., 2019b. Eggshell powder as partial cement replacement and its effect on the workability and compressive strength of concrete. International Journal of Advanced and Applied Sciences, 6(9), pp.71-75.

Jhatial, A. A., Goh, W. I., Mohamad, N., Sohu, S., \& Lakhiar, M. T. 2018. Utilization of Palm Oil Fuel Ash and Eggshell Powder as Partial Cement Replacement-A Review. Civil Engineering Journal, 4(8), 1977-1984.

Kamaruddin, S., Goh, W. I., Mutalib, N. A. N. A., Jhatial, A. A., Mohamad, N. \& Rahman, A. F., 2021. Effect of Combined Supplementary Cementitious Materials on the Fresh and Mechanical Properties of EcoEfficient Self-Compacting Concrete. Arabian Journal for Science and Engineering, pp.1-21.

Krishna, P. A. \& Kanaka, D. V. 2017. A Study on Strength of Fibre Reinforced Concrete with Palm Oil Fuel Ash as Partial Replacement of Cement. International Journal of Engineering Science and Computing (IJESC). Volume 7 Issue No. 7.

Kumar, R., Shafiq, N., Kumar, A. \& Jhatial, A. A. 2021. Investigating embodied carbon, mechanical properties, and durability of high-performance concrete using ternary and quaternary blends of metakaolin, nano-silica, and fly ash. Environmental Science and Pollution Research. https://doi.org/10.1007/s11356-021-13918-2

Lehne, J., \& Preston, F. 2018. Making Concrete Change. Innovation in Low-carbon Cement and Concrete. Cambridge: Chatham House, The Royal Institute of International Affairs.

Manandhar, R., Kim, J. H., \& Kim, J. T. 2019. Environmental, social and economic sustainability of bamboo and bamboo-based construction materials in buildings. Journal of Asian Architecture and Building Engineering, 18(2), 49-59.

Marinamarican, M. H. 2015. The Effect of Eggshell Powder on Concrete Brick Performance as Partial Replacement of Cement. Thesis. Universiti Malaysia Pahang; 2015

Memon, M.J., Jhatial, A.A., Murtaza, A., Raza, M.S. \& Phulpoto, K.B., 2021. Production of eco-friendly concrete incorporating rice husk ash and polypropylene fibres. Environmental Science and Pollution Research, pp.1-17. https://doi.org/10.1007/s11356-021-13418-3

Mignardi, S., Archilletti, L., Medeghini, L. \& De Vito, C., 2020. Valorization of eggshell Biowaste for sustainable environmental remediation. Scientific reports, 10(1), pp.1-10. https://doi.org/10.1038/s41598020-59324-5

Mohamad, N., Samad, A. A. A., Ali, N., Hadipramana, J., \& Jamaluddin, N. 2015. Performance of connected precast lightweight sandwich foamed concrete panel under flexural load. Jurnal Teknologi (Sciences \& Engineering), 75(9), 111-115.

Munir, A., Abdullah, Huzaim, Sofyana, Irfandia \& Safwana 2015. Utilization of palm oil fuel ash (POFA) in producing lightweight foamed concrete for non-structural building material. Procedia Engineering. 125, 739 $-746$.

Mydin, M. A. O. 2014. Models for Prediction the Strength and Stiffness of Foamed Concrete at Ambient Temperature. European Researcher. Vol. (67), No. 1 - 2.

Nivedhitha, M. \& Sivaraja, Dr. M. 2017. Experimental Study on Partial Replacement Cement with Coconut Shell Powder and Egg Shell Powder. International Journal of Innovative Research in Science Engineering and Technology. Vol. 6, Issue 5, May 2017.

Nordin, K. A., Adamu, M., Forouzani, P. \& Ismail, M. 2013. Performance of Waste Tyre and Palm Oil Fuel Ash Concrete. Malaysian Journal of Civil Engineering 25 (2): 177 - 189. 
Sata, V., Jaturapitakkul, C. \& Rattanashotinunt, C., 2010. Compressive strength and heat evolution of concretes containing palm oil fuel ash. Journal of materials in civil engineering, 22(10), pp.1033-1038.

Sooraj, V. M. 2013. Effect of Palm Oil Fuel Ash (POFA) on Strength Properties of Concrete. International Journal of Scientific and Research Publications. Vol. 3 Issue 6.

Suhendro, B., 2014. Toward green concrete for better sustainable environment. Procedia Engineering, 95 , pp.305-320.

Tonnayopas, D., Nilrat, F., Putto, K. \% Tantiwitayawanich, J., 2006. Effect of oil palm fiber fuel ash on compressive strength of hardening concrete. in Proceedings of the 4th Thailand Materials Science and Technology Conference, Pathumthani, Thailand, March 31-April 1, 2006, pp. 1-3.

Thomas, B.S., Kumar, S \& Arel, H. S., 2017. Sustainable Concrete Containing Palm Oil Fuel Ash as Supplementary Cementitious Material. Renewable and Sustainable Energy Reviews. 80 (2017) 550 - 561.

Yakovlev, G., Kerienė, J., Gailius, A. \& Girnienė, I., 2006. Cement based foam concrete reinforced by carbon nanotubes. Materials Science [Medžiagotyra], 12(2), pp.147-151.

Yerramala, A., 2014. Properties of concrete with eggshell powder as cement replacement. The Indian concrete journal, 88(10), pp.94-105.

Umar, M. S., Jennings, P. \& Urmee, T. 2013. Strengthening the Palm Oil Biomass Renewable Energy Industry in Malaysia. Renewable Energy. 60 (2013) 107 - 115. 